\title{
Hypoglicemic and Antioxidant Activities in Extracts Star Anise (Illcium Verum Hook.f) on Wistar Rat (Rattus norvegicus) Diabetes
}

\author{
Anna Maria Dewajanthi ${ }^{1}$, Agus Limanto $^{1}$, Clarita $^{1}$, Audrey Fidelia ${ }^{1}$ \\ ${ }^{1}$ Departemen Biokimia, Fakultas Kedokteran, Universitas Kristen Krida Wacana, Jl.Arjuna Utara No.6, Jakarta \\ Barat 11510, Indonesia \\ *Corresponding author: anna.dewajanthi@ukrida.ac.id
}

\section{ABSTRACT}

Diabetes mellitus is a disease that is quite common among the people. The causes of diabetes mellitus vary depending on the classification of this group of diseases. If diabetes mellitus is not handLed properly and correctly, there will be chronic hyperglycemia that causes oxidative stress, so patients will complain of some complications from diabetes mellitus that is actually caused by free radicals. Star anise (Illicium Verum) is one of the plants that are often used, one of which is as a spice in food. The star anise has several compounds, one of which is flavonoid which is as an easily oxidized compound (antioxidant), so it is often used as a traditional medicine to treat many diseases. In several studies in vitro this star anise plant has also been proven to have antioxidant levels such as flavonoids and phenolic which are high enough so that it can be used as a source of exogenous antioxidants that can help endogenous antioxidants such as glutathione (GSH) to reduce free radicals that enter and remain keep body cells in normal condition. The study was carried out experimentally and conducted on rats in diabetes mellitus to see the effect of giving star anise extracts on glucose levels and blood levels of endogenous antioxidants (glutathione). Male rats with 2-3 months of age as many as 24 animals were divided into 6 groups, namely the negative control group (mice only given distilled water), diabetic rats without treatment group (positive control), diabetic rats treated with rootbose (positive control), and diabetic rats by treating the extract of star anise of 50,100, and 150 $\mathrm{mg} / \mathrm{kg}$ body weight of rats. This research was conducted for 7 days. GSH levels were measured on days 0 and 7. To analyze the differences in the average data of glucose and GSH, statistics were used. Results of the Wilcoxon test showed that there were significant differences (with $p<$ 0.05 ) in blood sugar levels between the control group and the diabetic rats treated with star anise extract group. There was a significant decrease in blood sugar levels in diabetic rats given an extract of star anise. The greatest decrease in blood sugar levels occurred in the group of diabetic rats who were given an extract of star anise at $150 \mathrm{mg} / \mathrm{kg} \mathrm{bw}$. It is also known that there are difference in GSH levels between the control group and the diabetic rat group with the treatment of extract of star anise, but statistically the difference is not significant. GSH levels increased $0.03 \mu \mathrm{M} / \mathrm{mL}$ by administering an extract of star anise at $50 \mathrm{mg} / \mathrm{kg} \mathrm{bw}$.

Keywords: antioxidants, diabetes mellitus, free radicals, Glutathione (GSH), oxidative stress, rat, star anise (Illicium verum)

\section{ABSTRAK}

Diabetes Melitus merupakan penyakit yang cukup umum dikalangan masyakarat. Penyebab dari penyakit Diabetes Melitus (DM) sangat beragam tergantung klasifikasi kelompok penyakit ini. Jika penyakit diabetes tersebut tidak ditangani dengan baik dan tepat maka akan terjadi hiperglikemia kronik yang menyebabkan terbentuknya stress oksidatif, sehingga pasien akan mengeluhkan beberapa 
komplikasi dari penyakit DM yang sebenarnya disebabkan oleh peningkatan radikal bebas. Bunga lawang (Illicium Verum Hook.f) merupakan salah satu tanaman yang sering dipakai sebagai rempahrempah pada makanan. Bunga lawang mengandung senyawa aktif berupa fenolik dan flavonoid yang bersifat sebagai suatu senyawa yang mudah teroksidasi, sehingga dapat berperan sebagai antioksidan; Penelitian ini dilakukan secara eksperimental pada tikus dalam keadaan diabetes untuk melihat pengaruh pemberian ekstrak bunga lawang terhadap kadar glukosa dan kadar antioksidan endogen (GSH) darah. Tikus jantan dengan umur 2-3 bulan sebanyak 24 ekor di bagi dalam 6 kelompok, yaitu kelompok kontrol negatif (tikus hanya diberikan akuades), tikus diabetes tanpa perlakuan (kontrol positif), tikus diabetes dengan perlakukan pemberian akarbosa (kontrol positif), dan tikus diabetes dengan perlakuan pemberian ekstrak bunga lawang dosis 50, 100, dan $150 \mathrm{mg} / \mathrm{kg}$ berat badan tikus. Penelitian ini dilakukan selama 7 hari. Untuk analisa adanya perbedaan data rata-rata kadar glukosa dan GSH antar kelompok digunakan uji statistik. Dari hasil uji Wilcoxon terhadap data hasil penelitian diketahui bahwa terdapat perbedaan yang signifikan (dengan $\mathrm{p}<0.05$ ) pada kadar gula darah antara kelompok kontrol dengan kelompok tikus diabetes dengan perlakuan pemberian ekstrak bunga lawang. Terjadi penurunan kadar gula darah yang signifikan pada tikus diabetes yang diberikan ekstrak bunga lawang. Penurunan kadar gula darah terbesar terjadi pada kelompok tikus diabetes yang diberikan ekstrak bunga lawang dosis $150 \mathrm{mg} / \mathrm{kg}$ bb. Diketahui pula bahwa terdapat perbedaan kadar GSH antara kelompok kontrol dengan kelompok tikus diabetes dengan perlakuan pemberian ekstrak bunga lawang, tetapi secara statistik perbedaan tersebut tidak signifikan. Kadar GSH meningkat sebesar $0.003 \mu \mathrm{M} / \mathrm{mL}$ dengan pemberian ekstrak bunga lawang dosis $50 \mathrm{mg} / \mathrm{kg} \mathrm{bb}$.

Kata Kunci : antioksidan, bunga lawang (Illicium verum Hook.f), diabetes melitus, glutation (GSH), radikal bebas, stress oksidatif

\section{PENDAHULUAN}

Diabetes melitus (DM) merupakan penyakit metabolik yang mempunyai karakteristik hiperglikemia yang disebabkan oleh kurangnya atau terdapat kelainan pada sekresi insulin, kerja insulin, ataupun keduanya [1,2]. Menurut World Health Organization (WHO), diperkirakan terdapat 346 juta penderita diabetes di dunia, dan khusus di daerah Asia Tenggara diperkirakan hampir mencapai 71 juta orang menderita diabetes pada tahun 2010. Hampir 3,4 juta penderita di dunia dan 1 juta orang di daerah Asia Tenggara meninggal setiap tahunnya, akibat tingginya kadar gula darah [3].

Penderita diabetes melitus dalam rentang usia 20-79 tahun pada tahun 2015 mengalami perkembangan pesat hingga empat kali lipat dari tahun 1980-an. Hampir $80 \%$ orang diabetes berada di negara berkembang. Negara Indonesia menempati urutan ke tujuh di dunia dengan prevalensi orang diabetes mencapai 10 juta. Prevalensi Indonesia untuk kematian akibat diabetes merupakan peringkat ke dua setelah SriLanka [3].

Pada umumnya diabetes melitus ini dapat disebabkan oleh faktor genetik maupun lingkungan. Pada faktor genetik sering kali tidak dapat dilihat kapan awal atau pencetus pasti penyebab diabetes melitus tersebut. Tetapi pada faktor lingkungan terdapat awal mula atau pencetus dari diabetes melitus ini, yaitu seperti faktor sosial ekonomi, status gizi, asupan makanan, maupun gaya hidup (pola makan) dari penderita. Dengan adanya faktor lingkungan seperti asupan makanan yang tinggi karbohidrat atau lemak, serta gaya hidup (pola makan) yang tidak baik pada seseorang yang terjadi terus menerus, maka hal itu akan membuat seseorang menjadi obesitas, dan hal ini akan membuat aktivitas insulin akan menurun, sehingga terjadilah penyakit diabetes mellitus [4].

Kondisi hiperglikemia kronis akan menyebabkan meningkatnya produksi radikal bebas yang pada akhirnya terjadilah stress oksidatif. Stress oksidatif merupakan keadaan dimana jumlah radikal bebas (berupa molekul reaktif) dalam tubuh meningkat. Radikal bebas akan merusak membran sel dan menyebabkan berbagai gangguan pada fungsi organ tubuh. Stress oksidatif dapat menurunkan status antioksidan dalam tubuh dan dapat memicu komplikasi dari berbagai penyakit yang terjadi karena peningkatan produksi dari radikal bebas, salah satunya adalah diabetes [5]. 
Pada keadaan normal, tubuh dilindungi dari stress oksidatif oleh antioksidan alami yaitu, superoksida dismutase (SOD), katalase, Glutathion Peroxisade (GSH-Px), Glutathion tereduksi (GSH), asam urat, dan bilirubin. Namun bila jumlah radikal bebas yang terbentuk melampaui batas kemampuan antioksidan alami dalam tubuh untuk meredam, maka tubuh membutuhkan antioksidan dari luar tubuh.

Beberapa senyawa yang terkandung di dalam tanaman dan berpotensi sebagai antioksidan antara lain flavonoid, fenolik, dan alkaloid. Oleh karena itu, kita dapat memanfaatkan tanaman-tanaman herbal yang mengandung senyawa-senyawa sebagai antioksidan tersebut untuk menangkal beban oksidatif, sehingga dapat mempertahankan atau meningkatkan kadar antioksidan endogen. Salah satu contoh tanaman yang mengandung senyawa tersebut adalah bunga lawang atau biasa disebut star anise yang memiliki nama latin yaitu Illicium verum Hook.f [6].

Bunga lawang atau Illicium verum Hook, f. merupakan salah satu tanaman obat tradisional yang merupakan tanaman asli dari Negara Cina bagian barat daya yang juga digunakan untuk rempah-rempah pada makanan yang cukup terkenal di Indonesia. Dalam beberapa studi memaparkan bahwa tanaman bunga lawang ini merupakan suatu antimikroba, antifungal, antiinflamasi, antialergi, dan efek antikanker [7]. Studi lain menyatakan bahwa bunga lawang sering dipakai menjadi salah satu obat tradisional untuk mengobati banyak penyakit, seperti sakit perut, bronkitis, rematik, stimulan, dan diuretic [8]. Ekstrak bunga lawang dengan konsentrasi $1 \mathrm{mg} / \mathrm{mL}$ menggunakan pelarut akuades diketahui mengandung fenolik dan flavonoid sebesar $81.46 \mathrm{ppm}$ dan $16.97 \mathrm{ppm}$. Secara In Vitro tanaman ini telah diuji memiliki efek sebagai antioksidan, tetapi untuk penelitian tentang efek antioksidan dari bunga lawang secara In Vivo belum banyak diteliti. Pada penelitian secara in vivo ini, ekstrak bunga lawang diharapkan dapat digunakan sebagai sumber antioksidan eksogen yang dapat membantu kerja antioksidan endogen, salah satunya glutation (GSH), dalam menangkal radikal bebas dan tetap menjaga sel tubuh dalam keadaan normal.
Penelitian ini dilakukan untuk mengetahui apakah pemberian ekstrak bunga lawang (Illicium verum Hook.f) $0,5 \mathrm{~mL}$ dengan dosis 50,100 , dan $150 \mathrm{mg} / \mathrm{kg}$ berat badan (BB) dapat menurunkan kadar gula darah (memberi efek hipoglikemik) dan memberikan efek antioksidan (mempertahankan atau meningkatkan kadar GSH).

\section{METODE PENELITIAN}

\section{Bahan dan Alat}

Bahan utama yang digunakan adalah bunga lawang / star anise (Illicium verum Hook.f) yang telah kering yang berasal dari pasar tradisional. Bahan kimia yang digunakan akuades, etanol (96\%), aloksan tetrahidrat, $\mathrm{NaCl} 0.9 \%$, dinatrium hidrogen fosfat $\left(\mathrm{Na}_{2} \mathrm{HPO}_{4}\right) \quad 0.1 \mathrm{M}$, ditio bisnitro benzoate (DTNB), GSH standar, asam trikloroasetat (TCA) 5\%, alkohol 70\%, sodium dihidrogen fosfat $\left(\mathrm{NaH}_{2} \mathrm{PO}_{4}\right) 0.1 \mathrm{M}$, eter, strip glukosa dan CMC $0.5 \%$.

Alat yang diperlukan : evaporator rotary, spektrofotometer, tabung reaksi, Eppendorf (2 $\mathrm{ml}$ ), kandang hewan coba, sonde lambung, soxhlet, gelas ukur, glucometer, dan timbangan digital.

\section{Hewan Coba}

Tikus wistar jenis Rattus novergicus jantan, diperoleh dari Bagian Gizi Universitas Indonesia, berusia 2-3 bulan, berat 150-250 gram.

\section{Tempat Penelitian}

Penelitian dilakukan di Laboratorium Hewan (laboratory animal) dan Laboratorium Riset Fakultas Kedokteran dan Ilmu Kesehatan Universitas Kristen Krida Wacana

\section{Desain Penelitian}

Penelitian ini bersifat eksperimental. Tikus sebanyak 24 ekor dibagi menjadi 6 kelompok yaitu tiga kelompok tikus diabetes yang diberi perlakuan (diberikan ekstrak bunga lawang dengan dosis $50 \mathrm{mg} / \mathrm{kgBB}, 100$ $\mathrm{mg} / \mathrm{kgBB}$ dan $150 \mathrm{mg} / \mathrm{kgBB}$ ) dan tiga kelompok kontrol (kontrol positif tanpa perlakuan, kontrol positif dengan pemberian akarbosa, dan kontrol negatif) dengan randomisasi sederhana. Besar nya sampel penelitian untuk setiap kelompok perlakuan yaitu 4 sampel, sehingga total sampel menurut rumus Frederer adalah 24 tikus, didapatkan 
dari rumus: $t(n-1) \geq 15$. Penilaian dilakukan dengan membandingkan hasil observasi pada kelompok perlakuan dan kontrol.

\section{Induksi Aloksan dan Pengukuran Kadar Gula Darah}

Sebelum dilakukannya penginduksian aloksan, tikus dipuasakan selama 18 jam dan setelah itu kelompok kontrol negatif diinduksi dengan $\mathrm{NaCl} 0.9 \%$ dan selebihnya tikus diinduksi dengan aloksan dengan dosis 180 $\mathrm{mg} / \mathrm{kgBB}$ dengan volume $1 \mathrm{~mL} / 300 \mathrm{~g} \mathrm{BB}$ yang diberikan lewat intramuscular yang berada dibagian abdomen tikus. Setelah 3 hari, dilakukan pengukuran kadar gula darah. Pemberian aloksan bertujuan untuk membuat tikus diabetes [9]

Pengukuran kadar gula darah dilakukan menggunakan glukometer. Pengukuran kadar gula darah dilakukan dengan cara mengambil darah tikus sebanyak $1 \mathrm{~mL}$ melalui ekor setelah sebelumnya dibersihkan dengan alkohol terlebih dahulu. Lalu darah diteteskan pada strip glukometer dan kemudian strip dimasukkan ke dalam alat tersebut untuk dibaca hasilnya.

\section{Pembuatan Dosis Ekstrak Bunga Lawang}

Pembuatan ekstrak bunga lawang (Illicium verum) dilakukan dengan cara maserasi bubuk bunga lawang 50 gram dengan etanol $200 \mathrm{ml}$ selama 1 minggu. Setelah itu, dilakukan evaporasi untuk memisahkan pelarutnya (etanol) dari ekstrak yang diperoleh dengan menggunakan alat evaporator rotary, sehingga membuat larutan menjadi lebih kental. Setelah ekstrak diperoleh, maka dilakukan pembuatan dosis ekstrak bunga lawang. Ekstrak bunga lawang diberikan sebanyak $1 \mathrm{~mL}$ ke setiap tikus perlakuan setiap harinya, sebanyak 1 kali, sesuai dengan berat badan masing-masing tikus pada setiap kelompok perlakuan.

a. Dosis $50 \mathrm{mg} / \mathrm{kgBB}$

Pada dosis $50 \mathrm{mg} / \mathrm{kgBB}$, ekstrak bunga lawang ditimbang sebanyak 0.525 gram dilarutkan dalam $35 \mathrm{ml} \mathrm{CMC} 0.5 \%$.

b. Dosis $100 \mathrm{mg} / \mathrm{kgBB}$

Hasil ekstrak bunga lawang ditimbang sebanyak 1.05 gram dilarutkan dalam $35 \mathrm{ml}$ CMC $0.5 \%$.

c. Dosis $150 \mathrm{mg} / \mathrm{kgBB}$

Ekstrak bunga lawang ditimbang sebanyak 1.575 gram dilarutkan dalam $35 \mathrm{ml} \mathrm{CMC}$ $0.5 \%$
Pemberian ekstrak bunga lawang dilakukan secara oral yaitu dicekok menggunakan sonde lambung, dengan cara memasukkan sonde tersebut perlahan dari mulut sampai ke dalam esofagus bagian atas, agar dapat memasukkan ekstrak bunga lawang tersebut dengan mudah ke dalam lambungnya.

\section{Pembuatan Larutan Standar GSH}

Pada pembuatan larutan standar GSH, digunakan metode Ditio Bisnitro Benzoat (DTNB). Diperlukan larutan standar (glutation) dengan konsentrasi $2 \mathrm{mg} / \mathrm{ml}$ dalam dapar fosfat $0,1 \mathrm{M}$ dengan $\mathrm{pH}$ 8,0. Dibuat dalam beberapa tabung reaksi berisi larutan standar tersebut sebagai berikut : $0,0 \mu \mathrm{L}, 5,0$ $\mu \mathrm{L}, 20,0 \mu \mathrm{L}$, dan $25,0 \mu \mathrm{L}$ dan masing-masing dimasukkan kedalam tabung reaksi. Setelah itu, ditambahkan masing-masing tabung dengan dapar fosfat $0,1 \mathrm{M}$ dengan $\mathrm{pH} 8,0$ hingga volume mencapai $9 \mathrm{~mL}$. Ketika telah mencapai $9 \mathrm{~mL}$, ditambahkan $1 \mathrm{~mL}$ larutan TCA 5\% dan dikocok hingga homogen. Setelah itu, diambil 4,0 mL dari masingmasing tabung dan ditambahkan $0,05 \mathrm{~mL}$ reagen DTNB, sisa dari setiap tabung akan dijadikan blanko [10]. Selanjutnya dilakukan pengukuran serapan absorban larutan uji dan standar dengan spektrofotometer dengan panjang gelombang $412 \mathrm{~nm}$.

Pembuatan DTNB dapat dilakukan dengan cara siapkan bubuk DTNB sebanyak $39.6 \mathrm{mg}$ dan dilarutkan dalam $10 \mathrm{~mL}$ dapar fosfat $0.1 \mathrm{M} \mathrm{pH} 7$ [11]. Untuk pemeriksaan kadar GSH, maka dilakukan uji DTNB, dengan cara : sampel darah tikus sebanyak 50 $\mu \mathrm{L}$ ditambahkan $1,780 \mathrm{ml}$ dapar fosfat dengan $\mathrm{pH} 8,0$ dan $0,2 \mathrm{~mL}$ TCA $5 \%$. Setelah itu, semua larutan tersebut dikocok hingga homogen. Jika sudah homogen, larutan tersebut disentrifugasi dengan $3000 \mathrm{rpm}$ dalam 5 menit. Setelah selesai, kemudian 0,8 $\mathrm{mL}$ supernatan dari larutan tersebut dipisahkan, dan ditambahkan $10 \mu \mathrm{L}$ DTNB, lalu didiamkan selama 1 jam. Sisa dari supernatan dijadikan sebagai blanko. Setelah selesai, dilakukan pengukuran serapan absorban sampel dan blanko dengan menggunakan spektrofotometer dengan panjang gelombang $412 \mathrm{~nm}$ [10].

\section{Penetapan Kadar GSH}

Untuk menetapkan kadar GSH sampel darah tikus penelitian, digunakan persamaan regresi linear dari kurva yang dibuat dari 
larutan standar (glutation), $\mathrm{y}=\mathrm{ax}+\mathrm{b}$ di mana (y) adalah absorban dan (x) merupakan konsentrasi larutan standar.

\section{HASIL PENELITIAN}

\section{Pengaruh Ekstrak Bunga Lawang terhadap Kadar Gula Darah}

Aloksan dapat meningkatkan kadar gula darah pada seluruh kelompok. Aloksan bekerja dengan cara menginduksi keadaan stress oksidatif. Aloksan dan asam dialurat (hasil reduksi aloksan) mengalami reaksi siklus redoks melalui autooksidasi yang dapat menghasilkan spesies radikal superoksida dan hidrogen peroksida $\left(\mathrm{H}_{2} \mathrm{O}_{2}\right)$ dalam tubuh. Selanjutnya, hidrogen peroksida dengan adanya ion $\mathrm{Fe}$ (II) akan membentuk radikal $\mathrm{OH}$. Dengan adanya stress oksidatif tersebut dapat merusak sel $\beta$-pankreas pada tikus, sehingga terjadilah kondisi hiperglikemik atau biasa disebut dengan penyakit diabetes melitus $[12,13]$.

Setelah hewan coba diinduksi dengan aloksan dan dilakukan pemeriksaan 3 hari setelahnya (HO) dapat dilihat bahwa gula darah tikus yang mula-mulanya normal mengalami peningkatan. Pada tikus yang hanya di induksi dengan $\mathrm{NaCl}$ fisiologis tampak tidak mengalami peningkatan gula darah $(<135 \mathrm{mg} / \mathrm{dL})$ sedangkan tikus yang diinduksi dengan aloksan mempunyai gula darah yang meningkat sebesar 446,25 mg/dL. Hal ini menunjukkan bahwa kerja dari aloksan mampu meningkatkan gula darah atau membuat keadaan hiperglikemia pada tikus.

Setelah tikus hiperglikemia diberikan perlakuan menggunakan ekstrak bunga lawang (kelompok tikus perlakuan dosis 50, 100, dan $150 \mathrm{mg} / \mathrm{kg} \mathrm{bb}$ ), dapat dilihat bahwa kadar gula darah mengalami penurunan yang artinya ekstrak bunga lawang mempunyai pontensi kerja untuk menurunkan kadar gula darah pada tikus hiperglikemia menuju ke gula darah yang normal berkisar pada 50-135 $\mathrm{mg} / \mathrm{dL}$ (Gambar 1). Dari data kadar gula darah yang didapatkan membuktikan bahwa ekstrak bunga lawang mampu menurunkan kadar gula darah dalam 7 hari (H7) meskipun belum mengembalikan sampai kadar normal.

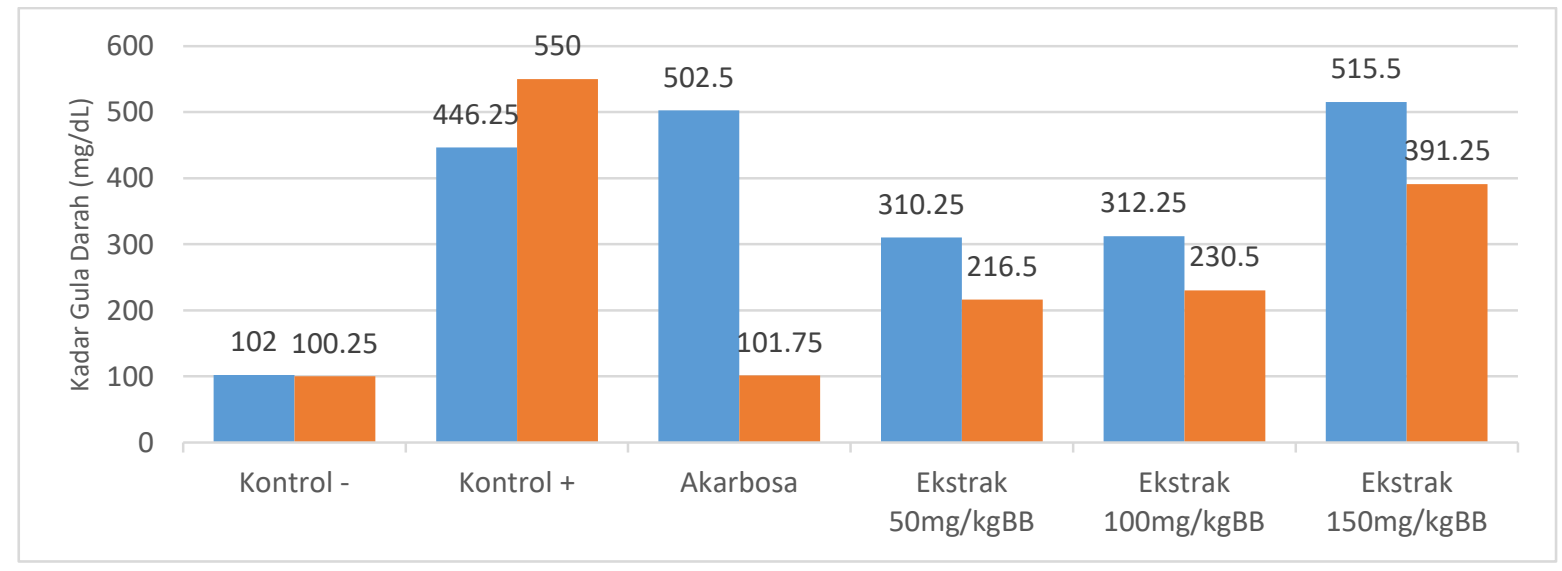

Gambar 1. Nilai Rata-Rata Kadar Gula Darah Tikus Sebelum (HO) dan Sesudah Induksi Aloksan (H7) Keterangan :

$\mathrm{H} 0=3$ hari setelah diinduksi aloksan

$\mathrm{H} 7=$ Hari ketujuh setelah perlakuan

Pada gambar 1 dapat dilihat bahwa pada kelompok tikus hiperglikemia yang diberikan akarbosa (kelompok kontrol positif dengan akarbosa) juga terjadi penurunan kadar gula darah dari 502,5 mg/dL menjadi $101,75 \mathrm{mg} / \mathrm{dL}$ pada hari ke-7, hal ini membuktikan bahwa akarbosa mampu menurunkan kadar gula darah pada tikus dalam waktu 7 hari, hingga mencapai kadar gula darah normalnya. Pada gambar tersebut juga memperlihatkan bahwa efek ekstrak bunga lawang sama dengan akarbosa yaitu dapat menurunkan kadar gula darah. 
Akarbosa merupakan kelompok obat inhibitor alfa-glukosidase yang bekerja secara kompetitif menghambat kerja enzim alfaglukosidase di dalam saluran cerna, khususnya usus halus yang berakibat pada penurunan penyerapan glukosa dan juga dapat menurunkan hiperglikemia postpradial [14]. Akarbosa merupakan salah satu obat yang tidak mempunyai efek samping hipoglikemia, hanya saja menyebabkan gas dalam perut meningkat [15].

Tabel 1 memperlihatkan perubahan kadar gula darah berupa penurunan kadar gula darah pada hari ke-7. Sama seperti pengaruh akarbosa, bunga lawang memiliki kemampuan untuk menurunkan kadar gula darah dalam 7 hari meskipun belum dapat menurunkan sampai kadar gula darah normalnya. Dosis ekstrak bunga lawang yang paling efektif menurunkan kadar gula darah ialah dosis 150 $\mathrm{mg} / \mathrm{kgBB}$ dengan selisih kadar gula darah yang paling besar yaitu $124.25 \mathrm{mg} / \mathrm{dL}$, meskipun pada hari ke-7 belum mencapai kadar gula darah yang normal. Bila dibandingkan dengan efek akarbosa terhadap penurunan kadar gula darah maka efek ekstrak bunga lawang dengan dosis $150 \mathrm{mg} / \mathrm{kgBB}$ masih belum sebaik efek pemberian akarbosa.

Tabel 1. Perubahan Rata-Rata Kadar Gula Darah Puasa Tikus (mg/dL) Sebelum dan Setelah Perlakuan

\begin{tabular}{cccc}
\hline Perlakuan & $\begin{array}{c}\text { Kadar Gula } \\
\text { Darah Sebelum } \\
\text { Perlakuan (H0) }\end{array}$ & $\begin{array}{c}\text { Kadar Gula } \\
\text { Darah Setelah } \\
\text { perlakuan }(\mathrm{H} 7)\end{array}$ & $\begin{array}{c}\text { Perubahan Kadar } \\
\text { Gula Darah }(\Delta)\end{array}$ \\
\hline Kontrol negatif & 102 & 100.25 & 1.75 \\
$\begin{array}{c}\text { Kontrol positif tanpa } \\
\text { perlakuan }\end{array}$ & 446.25 & 550 & $\begin{array}{c}103.75 \\
\text { (Kadar } \\
\text { meningkat) }\end{array}$ \\
$\begin{array}{c}\text { Kontrol positif dengan } \\
\text { pemberian akarbosa } \\
\text { Ekstrak Dosis } 50\end{array}$ & 502.5 & 101.75 & $400.75^{*}$ \\
mg/kgBB & 310.25 & 216.5 & 93.75 \\
$\begin{array}{c}\text { Ekstrak Dosis 100 } \\
\text { mg/kgBB }\end{array}$ & 312.25 & 230.5 & 81.75 \\
$\begin{array}{c}\text { Ekstrak Dosis 150 } \\
\text { mg/kgBB }\end{array}$ & 515.5 & 391.25 & $124.25^{*}$ \\
\hline
\end{tabular}

Untuk menguji normalitas data setiap kelompok perlakuan dilakukan uji Shapiro Wilk. Sebaran data normal ditemukan pada masing-masing H0 (3 hari setelah pemberian aloksan) dan $\mathrm{H} 7$ (hari ke-7 setelah diberikan aloksan) bila nilai $\mathrm{p}>0,05$. Untuk mengetahui adanya perbedaan yang signifikan antara data rata-rata kadar gula darah kelompok kontrol positif dengan pemberian akarbosa, kelompok kontrol positif (tikus hiperglikemia tanpa perlakuan), dan kontrol negatif (tikus normal), digunakan uji Wilcoxon. Dari hasil uji tersebut diperoleh $\mathrm{p}<0,05$ yaitu terdapat perbedaan yang signifikan pada hari ke-7 antara data ratarata kadar gula darah kelompok kontrol negatif dan kontrol positif (tanpa perlakuan) ; juga antara kontrol negatif dan kontrol positif dengan perlakuan akarbosa. Dapat disimpulkan bahwa data rata-rata kadar gula darah tikus diabetes yang mengkonsumsi akarbosa memiliki perbedaan yang signifikan dengan tikus diabetes tanpa perlakuan. Hal ini karena acarbosa merupakan obat untuk menurunkan kadar gula darah. Penelitian sebelumnya menyatakan bahwa pemberian 
akarbosa cukup efektif pada penurunan kadar gula darah tikus putih hiperglikemia [16].

Uji Wilcoxon juga dilakukan untuk mengetahui apakah terdapat perbedaan yang signifikan antara data rata-rata kadar gula darah kelompok kontrol positif dengan kelompok perlakuan yang diberikan ekstrak bunga lawang dosis 50, 100, dan 150 $\mathrm{mg} / \mathrm{kgBB}$ pada hari ke-7. Pada setiap uji diperoleh nilai $\mathrm{p}<0,05$ yang menyatakan adanya perbedaan antara data rata-rata kadar gula darah pada hari ke-7 kelompok kontrol positif dengan kelompok perlakuan yang diberikan setiap dosis ekstrak bunga lawang. Hal ini menunjukkan bahwa ekstrak bunga lawang memberikan efek penurunan kadar gula darah terhadap tikus hiperglikemia.

\section{Pengaruh Ekstrak Bunga Lawang terhadap Kadar Glutation Tereduksi (GSH)}

Untuk melakukan pemeriksaan kadar GSH (glutation tereduksi) pada plasma darah tikus, perlu dibuat terlebih dahulu kurva standar GSH. Standar GSH merupakan larutan GSH yang telah diketahui kadarnya. Pembuatan kurva standarnya, disajikan dalam bentuk linear dengan persamaan regresi linear sebagai berikut : $\mathrm{Y}=\mathrm{ax}+\mathrm{b}$, dan untuk nilai korelasi $\left(\mathrm{R}^{2}\right)>0.9$ yang berarti senyawa tersebut memiliki korelasi yang sangat kuat antara absorban (y) dan kosentrasi (x) [11].

Untuk pengukuran absorban larutan standar ini, digunakan panjang gelombang 412 nm. Pembuatan kurva standar menghasilkan persamaan linear $\mathrm{y}=154,24 \mathrm{x}+0.0237$ dengan nilai korelasi $\left(\mathrm{r}^{2}\right)=0.987$ yang artinya korelasi antara absorban (y) dan konsetrasi (x) sangat kuat. (Gambar 2).

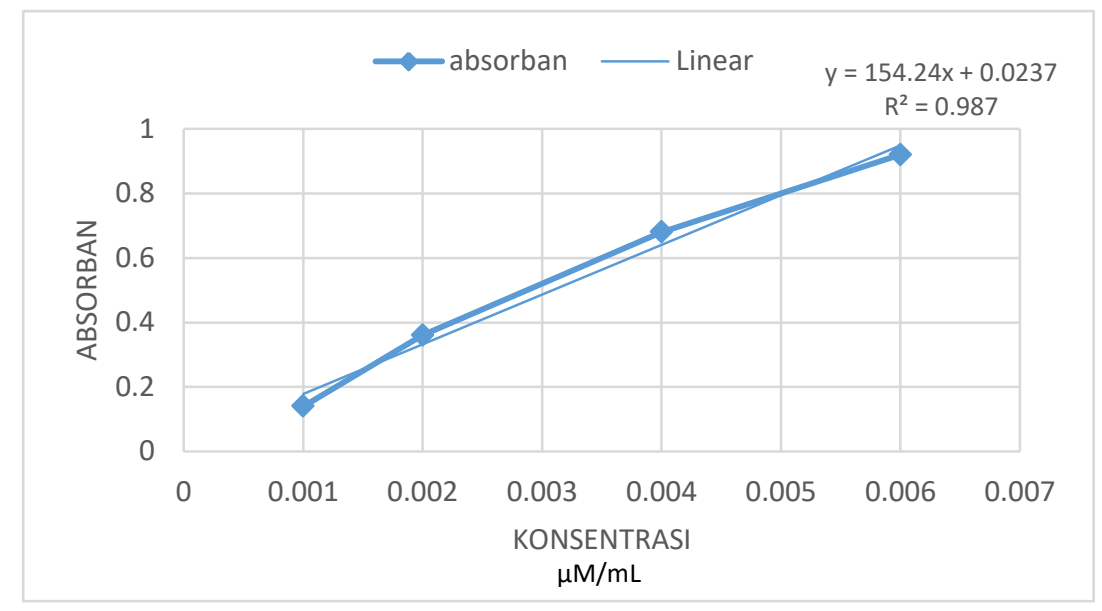

Gambar 2. Grafik Kurva Standar GSH

Kadar GSH sampel diperoleh dengan menggunakan persamaan regresi linear dari kurva standar yang telah diperoleh yaitu : $\mathrm{y}=$ $154,24 x+0.0237$, dimana sumbu y adalah absorban dan sumbu $\mathrm{x}$ adalah konsentrasi GSH. Gambar 3 memperlihatkan kadar GSH pada kelompok kontrol dan perlakuan pada hari ke-0 (sebelum perlakuan) dan hari ke-7 setelah perlakuan. Terjadi peningkatan kadar GSH pada kelompok perlakuan dengan pemberian ekstrak bunga lawang dosis 50 $\mathrm{mg} / \mathrm{kgBB}$ sebesar $0.003 \mu \mathrm{M} / \mathrm{mL}$, dan kadar GSH yang menetap (tidak berubah) pada dosis $100 \mathrm{mg} / \mathrm{kgBB}$, sedangkan pada kelompok perlakuan dengan pemberian ekstrak bunga lawang dosis $150 \mathrm{mg} \mathrm{/} \mathrm{kg}$ bb terjadi penurunan sebesar $0.001 \mu \mathrm{M} / \mathrm{mL}$ (Tabel 2).

Pada ekstrak bunga lawang diketahui mengandung senyawa-senyawa yang berpotensi sebagai antioksidan, seperti fenol dan flavonoid. Menurut penelitian Sri Winarsih dkk., diketahui di dalam ekstrak kasar bunga lawang dengan konsentrasi $1 \mathrm{mg} /$ $\mathrm{mL}$ terkandung fenolik dan flavonoid sebesar 81.46 ppm dan 16.97 ppm. Ekstrak bunga lawang yang diperoleh dengan metoda yang digunakan pada penelitian ini, juga berupa ekstrak 'kasar', dimana masih banyak senyawa lain yang tidak aktif sebagai antioksidan bercampur di dalam ekstrak tersebut, yang kemungkinan bersifat antagonis 
dengan kerja senyawa aktif dalam peranannya sebagai antioksidan. Pada ekstrak 'kasar' dengan dosis $50 \mathrm{mg} / \mathrm{kg}$ bb kemungkinan terdapat perbandingan yang baik antara senyawa aktif dan tidak aktif yang terdapat didalamnya, sehingga membuat ekstrak dosis ini lebih baik dalam kerjanya sebagai antioksidan dibandingkan dengan ekstrak bunga lawang dengan dosis yang lebih besar yaitu dosis 100 dan $150 \mathrm{mg} / \mathrm{kg} \mathrm{bb}$; kemungkinan di dalam dosis ekstrak bunga lawang yang lebih tinggi, komposisi senyawa yang memiliki aktivitas antioksidan tidak sebanyak pada dosis $50 \mathrm{mg} / \mathrm{kg}$ bb, sehingga menunjukkan aktivitas antioksidan yang lebih rendah.

Sebagai saran untuk penelitian berikutnya adalah dilakukan identifikasi kadar kandungan senyawa aktif yang berperan sebagai antioksidan yang terdapat di dalam ekstrak kasar bunga lawang dosis 50,100, dan $150 \mathrm{mg}$ $/ \mathrm{kg}$ bb dan untuk uji in vivo terhadap bunga lawang agar dibuat ekstrak yang lebih murni agar kandungan senyawa yang aktif sebagai antioksidan dapat diperoleh efek yang maksimal.

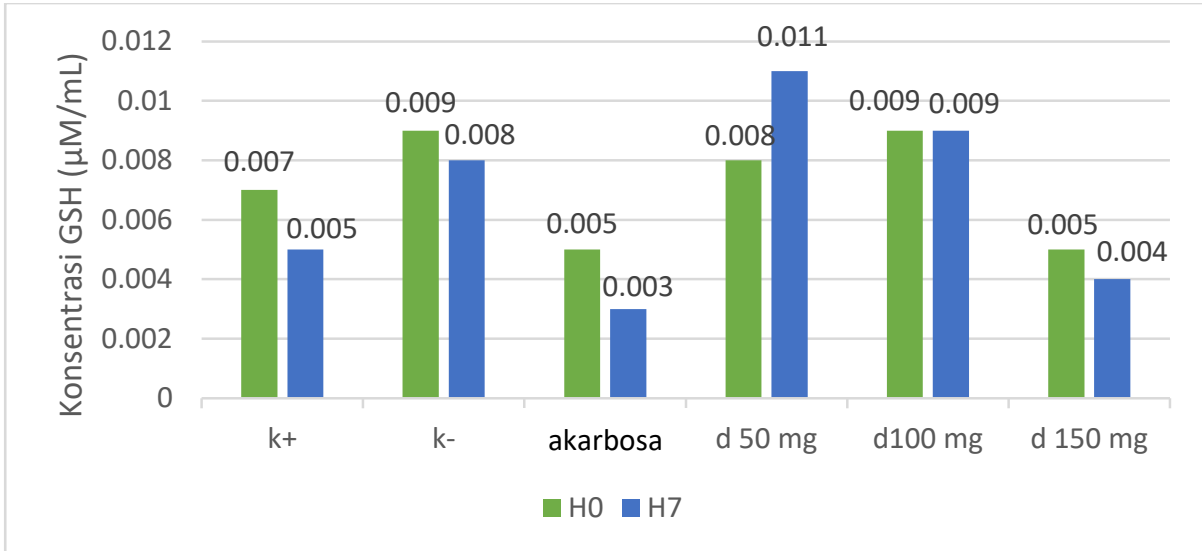

Gambar 3. Grafik Rata-Rata Kadar GSH pada Hari ke-0 dan ke-7.

Tabel 2. Perubahan $(\Delta)$ Rata-Rata Kadar GSH $(\mu \mathrm{M} / \mathrm{mL})$ Tiap Kelompok antara Hari Ke-0 dan Hari $\mathrm{Ke}-7$

\begin{tabular}{cccc}
\hline Keterangan & $\begin{array}{c}\text { Rerata kadar } \\
\text { GSH }\end{array}$ & $\begin{array}{c}\text { Rerata kadar } \\
\text { GSH } \\
\text { H0 }\end{array}$ & $\begin{array}{c}\text { Perubahan Kadar } \\
\text { GSH }\end{array}$ \\
& 0.009 & 0.008 & $\Delta$ \\
\hline Kontrol (-) & 0.007 & 0.005 & 0.001 \\
Kontrol (+) & 0.005 & 0.003 & 0.002 \\
Kontrol (+) & & & 0.002 \\
Akarbosa & 0.008 & 0.011 & \\
P1 & 0.009 & 0.009 & 0.003 \\
P2 & 0.005 & 0.004 & 0 \\
P3 & & & 0.001 \\
\hline
\end{tabular}

Pada kelompok tikus kontrol negatif, kontrol positif (tikus hiperglikemia yang tidak diberikan perlakuan), dan kelompok tikus hiperglikemia yang diberikan perlakuan dengan akarbosa terjadi penurunan kadar GSH pada hari ke- 7, dengan selisih kadar GSH sebesar 0.001, 0.002, dan $0.002 \mu \mathrm{M} / \mathrm{mL}$. Penurunan kadar GSH menunjukkan bahwa ketika terjadi peningkatan radikal bebas dalam tubuh akibat kondisi hiperglikemia kronik akan menyebabkan antioksidan endogen
(GSH) bekerja untuk meredam radikal bebas tersebut agar sel tidak mengalami kerusakan [17], sehingga terjadi penurunan kadar GSH.

Pada kelompok tikus hiperglikemia yang diberikan akarbosa menunjukkan bahwa pemberian akarbosa hanya dapat menurunkan kadar gula darah (lihat Gambar 1), tetapi tidak bekerja sebagai antioksidan untuk membantu kerja antioksidan endogen.

Untuk mengetahui apakah ada perbedaan yang signifikan rata-rata kadar GSH antara 
kelompok perlakuan dengan kelompok kontrol, maka dilakukan uji statistik. Sebelumnya sebaran data diuji normalitasnya menggunakan statistik Shapiro-Wilk dikarenakan data yang dipakai kurang dari 50 data. Setelah itu, untuk pemeriksaan data apakah ada perbedaan secara signifikan atau tidak digunakan One-way Anova pada data yang berdistribusi normal dan Wilcoxon pada data yang tidak berdistribusi normal.

Dari hasil uji One-way Anova data ratarata kadar GSH tidak memiliki perbedaan yang signifikan secara statistik (nilai $\mathrm{p}>0.05$ ), hal ini mungkin disebabkan oleh karena perlakuan pemberian ekstrak bunga lawang yang diberikan pada penelitian ini belum cukup lama (hanya selama 7 hari), sehingga perubahan kadar GSH setelah perlakuan kenaikannya hanya sedikit (Tabel 2).

Pada keadaan hiperglikemia dengan adanya pemberian ekstrak bunga lawang dengan dosis yang berbeda-beda $50 \mathrm{mg} / \mathrm{kgBB}$, $100 \mathrm{mg} / \mathrm{kbgBB}$, dan $150 \mathrm{mg} / \mathrm{kgBB}$, mengakibatkan kadar GSH yang awalnya rendah, pada hari ke-7 setelah perlakuan mengalami sedikit peningkatan (Tabel 2) yang secara statistik tidak signifikan. Pada bunga lawang ditemukan sejumlah senyawa yang diketahui merupakan senyawa antioksidan seperti fenolik dan flavonoid [18].

Pada penelitian ini penggunaan ekstrak bunga lawang kurang berpengaruh dalam membantu antioksidan endogen (GSH) untuk menangani stress oksidatif pada kondisi hiperglikemia, hal ini kemungkinan dikarenakan kadar ekstrak bunga lawang yang dosisnya masih terlalu rendah sehingga kurang kandungan antioksidannya dan tidak dapat secara signifikan menaikkan kadar atau mempertahankan kadar GSH dalam tubuh dalam waktu singkat sekitar 7 hari. Jika dibandingkan dengan penelitian yang lain menggunakan sari jengkol, diketahui dalam waktu 8 hari diperoleh adanya perbedaan data kadar GSH yang siginifikan (nilai $\mathrm{p}<0.05$ ) [17].

\section{KESIMPULAN}

Hasil penelitian menujukkan bahwa ekstrak bunga lawang dapat menurunkan kadar gula darah pada tikus hiperglikemia. Penurunan kadar gula darah terbesar yaitu terjadi pada kelompok tikus hiperglikemia yang diberikan ekstrak bunga lawang dosis $150 \mathrm{mg} / \mathrm{kg} \mathrm{bb}$, dibandingkan dosis lainnya.

Ekstrak bunga lawang dengan dosis 50, 100, dan $150 \mathrm{mg} / \mathrm{kgBB}$ mampu mempertahankan atau meningkatkan kadar GSH pada hari ke-7, meskipun secara statistik tidak significan, hal ini mungkin dapat disebabkan karena dosis ekstrak bunga lawang yang diberikan pada tikus hiperglikemia belum cukup efektif atau waktu pemberian perlakuan yang kurang cukup untuk membantu mempertahankan ataupun meningkatkan kadar GSH pada tubuh.

\section{DAFTAR PUSTAKA}

[1] Sejati NIP. (2016). Pengaruh minuman yang diperkaya cinnulin terhadap parameter diabetik responden diabetes melitus tipe-2. Bogor: Sekolah Pascasarjana Institut Pertanian Bogor.

[2] Widowati W. (2008). Potensi Antioksidan sebagai antidiabetes. JKM.: 7(2); $1-5$.

[3] WHO, Regional office for South East Asia. (2012). Diabetes fact sheet, Department of Sustainable Development and Healthy Environments. Available from : https://www.who.int/docs/defaultsource/searo/nde/sde-diabetes-

fs.pdf?sfvrsn=7e6d411c_2 Accessed by April 2020.

[4] Anita DCK. (2013). Kadar glukosa darah dan malondialdehid ginjal tikus diabetes yang diberi latihan fisik. Muhammadiyah Journal of Nursing 1(1)

[5] Riyanti H, Simanjuntak SBI, Winarsi H. (2014). Aktivitas glutation peroksidase dan kadar gula darah tikus diabetes yang diberi ekstrak daun kapulaga (Amomum cardamomum). Scripta Bilogica. 1(2): 153-155.

[6] Aly SE, Bassem SA, Shaheen MS, Hathout AS. (2014). Assement of antimycotoxigenic and antioxidant activity of star anise (Illicium verum) In Vitro. Journal of the Saudi Society of Agricultural Sciences. 1(1): 4-6.

[7] Zhou BG, Wang S, Dou TT, Liu S, Li MY, Hua RM, (2016). Aphicidal activity of Illicium verum fruit extracts and their effects on the acetylcholinesterase and glutathione S-transferases activities in myzus persicae (Hemiptera: Aphididae). Journal of Insect Science. 16(1). 
[8] Lim TK. (2012). Edible medicinal and non-medicinal plants. London: Springer Dordecht Heidelberg. p. 159-60

[9] Akrom, Harjanti PD, Armansyah T. (2014). Efek hipoglikemik ekstrak etanol umbi ketela rambat (Ipomoea batatas P) pada mencit swiss yang diinduksi aloksan. Pharmaciana 4(1): 65-70.

[10] Widowati L, Sadikin M, (2004). Wahjoedi B. Aktifitas antioksidan ekstrak biji klabet (Trigonella foenum-graecum L.) : Pengukuran kadar glutation tikus diabetes. Media Litbang Kesehatan vol. XIV (4) : $7-13$.

[11] Padmaningrum RT, Marwati S. (2015). Validasi metode analisis siklamat secara spektrofotometri dan turbidimentri. J. Sains Dasar 4(1): 23-29.

[12] Hasanah A. (2015). Efek jus bawang bombay (Allium cepa linn.) terhadap motilitas spermatozoa mencit yang diinduksi streptozotocin (STZ). Perbandingan Penggunaan Fikaisi Hair Spray Fikasi Rutin. Desember 11(2): 93

[13] Muqsita V, Sakinah EN, Santosa A. (2015). Efek ekstrak etanol kayu manis (Cinnamomum burmannii) terhadap kadar MDA ginjal pada tikus wistar hiperglikemi. E-Journal Pustaka Kesehatan. 3(2): 235-38.

[14] Velina Y. (2012). Deteksi dan kloning gen inhibitor $\alpha$-glukosidase Streptomyces sp. BWA 65 serta potensinya sebagai anti hiperglikemik pada mencit (mus musculus). Bogor: Institut Pertanian Bogor; h. 6-10.

[15] Istiana SD. (2016). Aktivitas antidiabetes kombinasi. Jawa Tengah: Fakultas Farmasi Universitas Muhammadiyah Purwokerto. h. 4-10.

[16] Budianto NEW, Hairullah. (2017). Perbedaan efektivitas akarbosa dengan ekstrak etanol kulit terong ungu (Solanum melongena L) terhadap penurunan kadar gula darah tikus putih (Rattus norvegicus) yang diinduksi surkosa. Jurnal Ilmiah Kedokteran Wijaya Kusuma , 6(2) : 1420

[17] Rusdi F, Sadikin M, Prijanti AR. (2013). Peran sari biji jengkol (Archidendron pauciflorum) dalam mencegah kerusakan hati Sprague dawley yang disebabkan oleh karbon tetraklorida dengan indikator glutation hati. Depok: Fakultas
Kedokteran Universitas Indonesia; h. 610.

[18] Chouksey D, Sharma P, Pawar RS. (2010). Biological activities and chemical constituents of Illicium verum hook fruits (Chinese Star Anise). Pelagia Research Library. 1(3): 1-5. 